\title{
Arsenic in Water Resources of the Southern Pampa Plains, Argentina
}

\author{
Juan D. Paoloni, ${ }^{1}$ Mario E. Sequeira, ${ }^{2}$ Martín E. Espósito, ${ }^{3}$ Carmen E. Fiorentino, ${ }^{3}$ \\ and María del C. Blanco ${ }^{3}$ \\ ${ }^{1}$ Consejo Nacional de Investigaciones Científicas y Técnicas (CONICET), San Andrés 850, 8000 Bahía Blanca, Argentina \\ ${ }^{2}$ Departamento de Ingeniería, Universidad Nacional del Sur. Consejo Nacional de Investigaciones Científicas y Técnicas \\ (CONICET-CERZOS), Avenida Alem 1253, 8000 Bahía Blanca, Argentina \\ ${ }^{3}$ Departamento de Agronomía, Universidad Nacional del Sur, San Andrés 850, 8000 Bahía Blanca, Argentina
}

Correspondence should be addressed to Juan D. Paoloni, jpaoloni@criba.edu.ar

Received 14 November 2008; Accepted 14 June 2009

Recommended by Kirby C. Donnelly

\begin{abstract}
Confronted with the need for accessible sources of good quality water and in view of the fact that the threat to public health posed by arsenic occurs mainly through the ingestion of contaminated drinking water, the presence and distribution of arsenic was evaluated in the southern Pampa Plains of Bahía Blanca district in Argentina. The findings show variable concentrations of arsenic in a complex distribution pattern. Complementary information is provided on the behavior of the groundwater resource and its salinity in terms of dissolved ions. Groundwater is the most severely affected, $97 \%$ of the samples exceeding the guideline value for arsenic in drinking water as recommended by the WHO (Guidelines for Drinking Water Quality, 2004). and showing maximum concentrations of up to $0.30 \mathrm{mg} / \mathrm{L}$. Informing those responsible for preventive medicine and alerting the community at large will facilitate measures to mitigate exposure and ensure the safety of drinking water.
\end{abstract}

Copyright ( $) 2009$ Juan D. Paoloni et al. This is an open access article distributed under the Creative Commons Attribution License, which permits unrestricted use, distribution, and reproduction in any medium, provided the original work is properly cited.

\section{Introduction}

The need to provide safe and accessible supplies of water to cover at least the basic requirements of the world's growing population is increasingly becoming a concern not only for international organizations dealing with this subject but also for policy-makers responsible for meeting demand in those regions most at risk from chronic water shortage [1].

Considerable literature has been published in recent years reporting the detection of arsenic in groundwater used for human consumption in new areas around the globe [2-6] and particularly in Argentina [7-9], where research on this etiologic agent of hydroarsenicism dates back to the early 20th century [10].

The consumption of contaminated water over long periods of time is the primary route of human exposure to arsenic [11]. However, medical toxicologists lack basic information on the presence and distribution of this ion in drinking water, thus hindering their ability to take preventive action and restricting them to the treatment of those already affected. Lesions to the skin, skin cancer, various other types of cancer (lung, kidney, liver, bladder), peripheral neuropathology's, and vascular pathologies (such as blackfoot disease) are all health problems commonly associated with long-term drinking of arsenic-contaminated water.

In view of its toxicity and the large number of people exposed to its effects worldwide, arsenic is an environmental contaminant that imposes a high risk of morbidity and mortality [12]. It is highly likely that in many as yet untested areas of Argentina, the population is drinking water with excessive concentrations of arsenic. The more studies undertaken on a country's water resources, the more evidence there is of the presence of this contaminant. According to Hopenhayn [12] limited data are available regarding the extent of arsenic contamination high-risk areas of Argentina. Thus, because 
of the delayed onset of illness, forty years or more may pass from the time of exposure until hydroarcenicism is diagnosed.

The present study was motivated by the high concentrations of arsenic found in groundwater of the southwest of the province of Buenos Aires, Argentina [13-15], and aims at evaluating arsenic concentrations, determining the spatial distribution of this contaminant in the southern Pampa Plains of Bahía Blanca district, and ultimately gauging the incidence risk in the environment of the local community, which has the region's highest population density.

\section{Materials and Methods}

The study was carried out over an area of $2300 \mathrm{~km}^{2}$ in the southern Pampa Plains of Argentina within the Bahía Blanca district, which has a population of approximately 320000 and borders on the Atlantic coast. The coordinates of the city of Bahía Blanca are Latitude $38^{\circ} 44^{\prime} \mathrm{S}$ and Longitude $62^{\circ} 16^{\prime}$ W of Greenwich (Figure 1).

Undulating plains and a moderate climate characterize the area, the main economic activities being in the agriculture and livestock sectors, with a considerable and stable resident rural population. Farming and ranching activities have impinged heavily on water and soil resources over the last century. These activities have gradually degraded resources in the absence of sustainable management techniques-despite some limited attempts at conservationism - and in the face of intensified anthropic use. The economy of the region depends in great measure on the quantity and quality of accessible water.

The cartographical information used for the study is based on maps of the Instituto Geográfico Militar (Military Geographical Institute), scales $1: 50,000$ and $1: 100,000$, and Landsat rural maps and images. A total of 81 water samples and three replicates were gathered through selective sampling in wells and perforations in use and in streams and minor water courses (Figure 2). Groundwater was extracted by means of windmills and centrifuge pumps, or similar. The water samples were collected in sterile $500 \mathrm{~mL}$ polyethylene containers and after filtration were subjected to the following analyses: $\mathrm{pH}$ (potentiometer), electrical conductivity (conductimeter), hardness, dissolved solids (evaporation), calcium + magnesium (versenate method), calcium, sodium and potassium (photometry), magnesium (EDTA complexometry), sulfates (turbidimetry), carbonates and bicarbonates (volumetry with sulfuric acid), nitrates (specific electrodes), and phosphates. However, according to our objective, here in solely electrical conductivity, water table depth and arsenic concentrations in phreatic and surface waters are reported (Tables $1 \mathrm{a}, 1 \mathrm{~b}$, and 1c). The depth and temperature of the water were recorded for all samples.

The concentration of arsenic in water was determined by Hydride Generation and Inductively Coupled Plasma Emission and Inductively Coupled Plasma Atomic Emission Spectroscopy (ICP-AES; detection limit $0.33 \mathrm{ppb}$ ) based on the method of [16], involving the continuous generation of arsenic $\left(\mathrm{AsH}_{3}\right)$ using three of the four channels of a peristaltic pump (Cole Palmer Instruments Co, Masterflex).
The sample solution and a solution of sodium tetrahydroborate plus potassium iodate were transported to a modified liquid-gas separator. The arsine and the hydrogen were captured from the separator to the plasma by a continuous flow of argon. Arsenic was determined according to the length of its main wave at $193.69 \mathrm{~nm}$. Boron, fluoride, chrome, vanadium, and other toxic elements were analyzed by Inductively Coupled Plasma (ICP). The chemical analyses were subjected to quality control through standard solutions for ICP; an Aldrich solution for arsenic was used as a reagent blank to obtain calibration curves for quality assurance being the analytical better than 5\%.

The hydrodynamics of the phreatic levels are presented in an isohypsic chart and the geographical distribution of total soluble salt concentrations and of arsenic are given in isoconcentration maps.

\section{Results}

Situated at the transition from Pampean to Patagonian landscape, in geomorphological terms, the study area can be described predominantly as a plain characterized by a general level of planation [17], closely associated with the lithographic, structural, and sedimentary factors predominating in the region. A notable series of undulations and gently carved intermediate terraces descend stepwise from the plain to the narrow stretches of alluvial flats in the valleys that traverse the area from the northeast to the south and southwest in search of their base level, before eventually reaching the Atlantic coast at Bahía Blanca. A predominance of loess from the Pampean Formation intercalates with petrocalcic horizons, the relief varying from 210 to $0 \mathrm{~m}$ above sea level and the average general slope being $0.5 \%$.

The depth of the water in the wells and perforations varies from $1.2 \mathrm{~m}$ at the bottom of the valleys and close to the riverbeds to $55.8 \mathrm{~m}$ in the more elevated interfluve area. The morphology of the phreatic surface shows a notable symmetry, with a steep hydraulic gradient in the order of $4.5 \%$ in the western sector and $2.8 \%$ in the east, markedly parallel isohipses, and a clear orientation of the discharge towards the maritime coast (Figure 3 ).

In evaluating the results it was considered useful to have information on electrical conductivity since this parameter indicates increases in salinity as a function of increases in dissolved ion content, giving a clear diagnosis of the degree of salinity of the studied waters. The values observed for surface water were from $0.59 \mathrm{dS} / \mathrm{m}$ to $3.35 \mathrm{dS} / \mathrm{m}$, the increase in salinity being particularly marked in water from the western sector of Bahía Blanca area (Figure 4). There was greater variability in the groundwater, showing a sequence of values from $0.30 \mathrm{dS} / \mathrm{m}$ to a maximum of $8.09 \mathrm{dS} / \mathrm{m}$. The isoconductivity lines indicate the spatial behaviour of total soluble salts, showing a considerable increase in the concentrations in the extreme southwest of the area (Figure 5).

The results from the chemical analysis of water (Tables $1(\mathrm{a}), 1(\mathrm{~b})$, and 1(c)) indicated that arsenic was detected in all the samples, the lowest values being found in 19 samples collected from surface water, with concentrations varying 
TABLE 1: Set of water samples: Bold Font indicates surface waters analysis and the others values correspond to phreatic waters.

(a)

\begin{tabular}{|c|c|c|c|c|}
\hline Latitude & Longitude & Depth $(\mathrm{m})$ & $\mathrm{Ce}(\mathrm{dS} / \mathrm{m})$ & As $(\mathrm{mg} / \mathrm{l})$ \\
\hline S38 4435.4 & W62 0840.9 & 18.3 & 1.54 & 0.30 \\
\hline S38 4209.4 & W62 0409.8 & 15.0 & 1.91 & 0.17 \\
\hline S38 4134.2 & W61 5631.0 & 13.4 & 1.46 & 0.15 \\
\hline S38 4129.9 & W61 5422.4 & - & 0.61 & 0.01 \\
\hline S38 3943.7 & W61 5242.8 & 13.0 & 1.27 & 0.25 \\
\hline S38 3948.1 & W61 4700.0 & 21.6 & 0.30 & 0.08 \\
\hline S38 3654.3 & W61 4607.2 & 33.3 & 1.24 & 0.13 \\
\hline S38 3158.8 & W61 4858.3 & 33.0 & 0.74 & 0.07 \\
\hline S38 3422.1 & W61 5153.0 & 13.0 & 1.26 & 0.07 \\
\hline S38 3656.3 & W61 5736.1 & 17.0 & 1.21 & 0.25 \\
\hline S38 3846.9 & W62 0105.3 & 6.7 & 2.34 & 0.05 \\
\hline S38 3200.7 & W61 5238.6 & 7.5 & 0.93 & 0.12 \\
\hline S38 3200.9 & W61 5227.0 & - & 0.59 & 0.01 \\
\hline S38 2906.7 & W61 4743.7 & 4.7 & 0.66 & 0.02 \\
\hline S38 2621.1 & W61 5001.7 & 12.6 & 1.53 & 0.02 \\
\hline S38 2735.5 & W61 5210.7 & 6.7 & 0.55 & 0.04 \\
\hline S38 2437.8 & W61 5621.6 & - & 0.53 & 0.01 \\
\hline S38 2554.0 & W61 5741.5 & 7.0 & 0.80 & 0.02 \\
\hline S38 2934.3 & W61 5502.9 & 4.7 & 1.19 & 0.03 \\
\hline S38 3146.8 & W61 5901.0 & 5.2 & 1.17 & 0.05 \\
\hline S38 3410.2 & W62 0020.5 & 24.5 & 1.13 & 0.16 \\
\hline S38 4048.1 & W62 0718.7 & 27.0 & 2.35 & 0.09 \\
\hline S38 3917.0 & W62 1616.4 & 38.0 & 2.33 & 0.07 \\
\hline S38 2801.6 & W62 0024.5 & 8.7 & 0.70 & 0.10 \\
\hline S38 2409.9 & W62 0617.8 & 29.3 & 0.61 & 0.03 \\
\hline S38 2605.9 & W62 0333.0 & - & 1.27 & 0.01 \\
\hline S38 2730.2 & W62 0257.9 & 23.4 & 0.87 & 0.05 \\
\hline S38 3020.6 & W62 0323.7 & 3.5 & 1.94 & 0.02 \\
\hline
\end{tabular}

(b)

\begin{tabular}{|c|c|c|c|c|}
\hline Latitude & Longitude & Depth $(\mathrm{m})$ & $\mathrm{Ce}(\mathrm{dS} / \mathrm{m})$ & As $(\mathrm{mg} / \mathrm{l})$ \\
\hline S38 3015.7 & W62 0331.4 & - & 1.02 & 0.01 \\
\hline S38 3540.5 & W62 0356.4 & 24.3 & 1.60 & 0.16 \\
\hline S38 3526.0 & W62 0515.5 & - & 1.22 & 0.01 \\
\hline S38 3715.3 & W62 0642.5 & 27.3 & 1.50 & 0.10 \\
\hline S38 3833.7 & W62 1130.6 & 10.0 & 2.79 & 0.04 \\
\hline S38 3314.8 & W62 0600.8 & 27.0 & 1.46 & 0.08 \\
\hline S38 3156.8 & W62 0829.1 & 17.0 & 0.62 & 0.02 \\
\hline S38 2925.6 & W62 0659.2 & 47.5 & 0.73 & 0.07 \\
\hline S38 2925.2 & W62 1019.7 & 31.5 & 1.31 & 0.04 \\
\hline S38 2626.0 & W62 0808.4 & 43.7 & 3.27 & 0.07 \\
\hline S38 2513.1 & W62 1412.4 & 31.8 & 1.25 & 0.08 \\
\hline S38 2857.5 & W62 1230.8 & 22.0 & 1.33 & 0.08 \\
\hline S38 2624.1 & W62 0957.4 & 55.8 & 1.37 & 0.07 \\
\hline S38 3331.0 & W62 1246.0 & 13.3 & 1.89 & 0.07 \\
\hline S38 3611.4 & W62 0941.4 & 4.8 & 1.33 & 0.18 \\
\hline S38 3539.2 & W62 1707.0 & 14.8 & 2.40 & 0.09 \\
\hline S38 3110.0 & W62 1622.1 & 23.7 & 1.54 & 0.01 \\
\hline S38 2545.3 & W62 1647.6 & - & 3.35 & 0.04 \\
\hline
\end{tabular}


(b) Continued.

\begin{tabular}{|c|c|c|c|c|}
\hline Latitude & Longitude & Depth (m) & $\mathrm{Ce}(\mathrm{dS} / \mathrm{m})$ & As $(\mathrm{mg} / \mathrm{l})$ \\
\hline S38 2332.2 & W62 1554.7 & 23.0 & 1.41 & 0.08 \\
\hline S38 2532.0 & W62 1902.5 & 6.7 & 1.32 & 0.08 \\
\hline S38 2604.5 & W62 2001.8 & - & 2.42 & 0.07 \\
\hline S38 3943.0 & W62 2019.0 & - & 2.72 & 0.06 \\
\hline S38 3835.4 & W62 2212.5 & 10.0 & 4.96 & 0.06 \\
\hline S38 3542.7 & W62 2312.3 & 1.8 & 2.77 & 0.16 \\
\hline S38 3247.3 & W62 2319.5 & 20.0 & 1.35 & 0.06 \\
\hline S38 2941.6 & W62 2230.3 & 27.0 & 1.24 & 0.03 \\
\hline S38 2609.7 & W62 2319.0 & 26.4 & 1.22 & 0.07 \\
\hline S38 3037.3 & W62 2636.3 & 16.4 & 1.08 & 0.04 \\
\hline Latitude & Longitude & Depth (m) & $\mathrm{Ce}(\mathrm{dS} / \mathrm{m})$ & As $(\mathrm{mg} / \mathrm{l})$ \\
\hline S38 2830.5 & W62 2630.4 & 11.3 & 1.06 & 0.04 \\
\hline S38 2811.1 & W62 2736.6 & - & 2.59 & 0.04 \\
\hline S38 3957.7 & W62 2718.5 & 4.2 & 8.09 & 0.16 \\
\hline S38 3918.9 & W62 2633.4 & - & 3.06 & 0.09 \\
\hline S38 3755.3 & W62 3140.6 & 2.0 & 1.81 & 0.07 \\
\hline S38 3757.4 & W62 3136.2 & - & 3.03 & 0.13 \\
\hline S38 3533.1 & W62 3613.0 & 5.2 & 1.45 & 0.08 \\
\hline S38 3341.4 & W62 3305.1 & - & 3.18 & 0.10 \\
\hline S38 3417.1 & W62 3122.7 & 21.7 & 0.69 & 0.07 \\
\hline S38 3535.7 & W62 2928.0 & - & 3.03 & 0.09 \\
\hline S38 3622.4 & W62 2651.3 & 20.0 & 3.05 & 0.05 \\
\hline S38 3744.7 & W62 2451.4 & 17.6 & 4.23 & 0.04 \\
\hline S38 4008.3 & W62 1911.7 & 6.5 & 5.74 & 0.09 \\
\hline S38 3257.1 & W62 1905.0 & 7.3 & 2.70 & 0.04 \\
\hline S38 3400.1 & W61 5633.2 & 5.1 & 1.51 & 0.05 \\
\hline S38 4233.8 & W61 5936.1 & 9.7 & 2.07 & 0.10 \\
\hline S38 3904.0 & W62 2441.4 & 3.6 & 7.0 & 0.15 \\
\hline S38 3947.0 & W62 2838.0 & - & 6.9 & 0.01 \\
\hline S38 3956.6 & W62 2846.5 & 3.1 & 0.9 & 0.02 \\
\hline S38 4050.4 & W62 2724.4 & 1.7 & 1.1 & 0.02 \\
\hline S38 4100.7 & W62 2601.4 & 1.2 & 2.2 & 0.09 \\
\hline S38 4133.0 & W62 1516.2 & - & 2.1 & 0.05 \\
\hline S38 2910.7 & W61 4707.1 & - & 1.1 & 0.08 \\
\hline S38 4206.8 & W62 2728.1 & - & 1.2 & 0.03 \\
\hline S38 3329.9 & W62 3740.1 & - & 1.1 & 0.03 \\
\hline
\end{tabular}

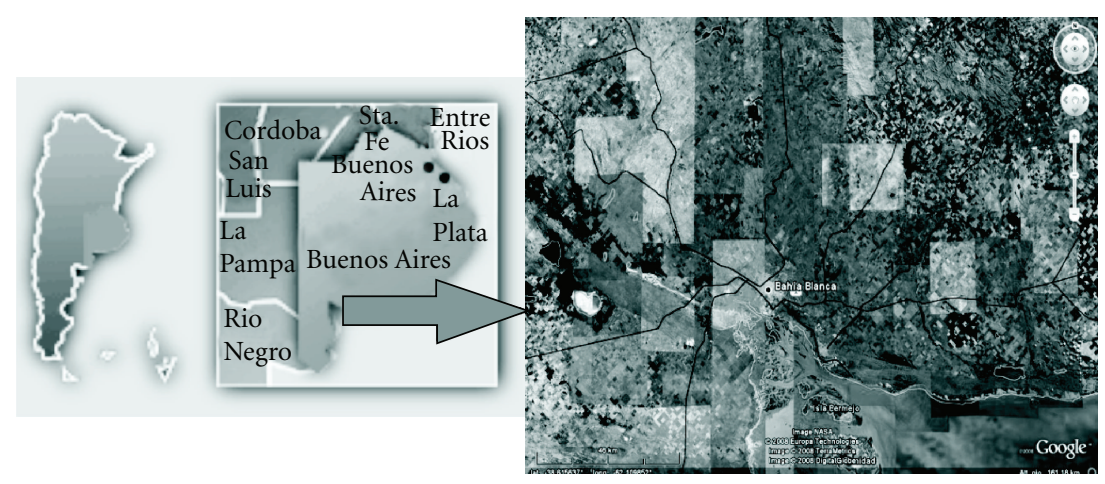

Figure 1: Southern Pampa Plains and Bahía Blanca, Argentina-Geographical location. 


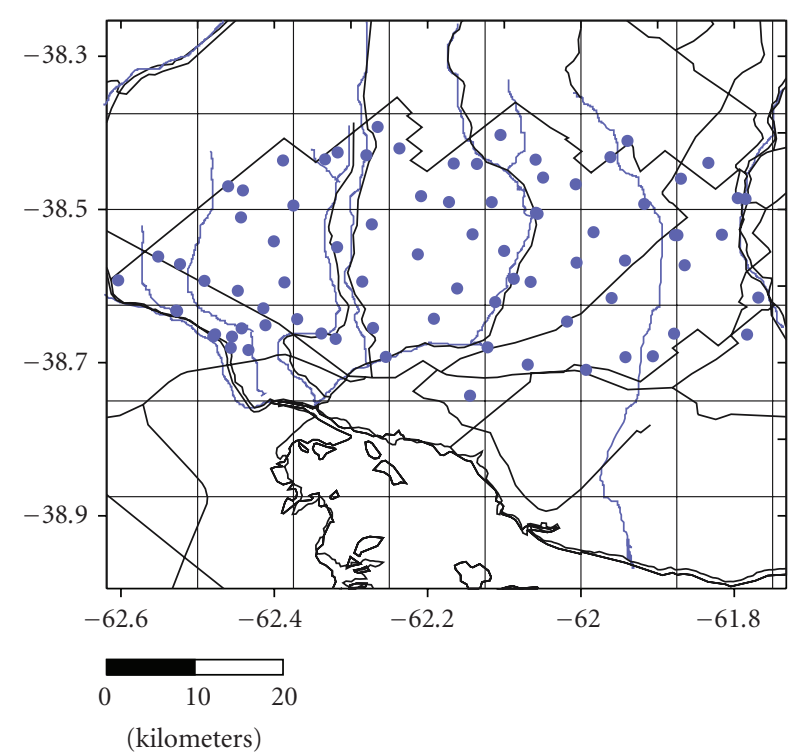

Figure 2: Map of surface and groundwater sampling sites.

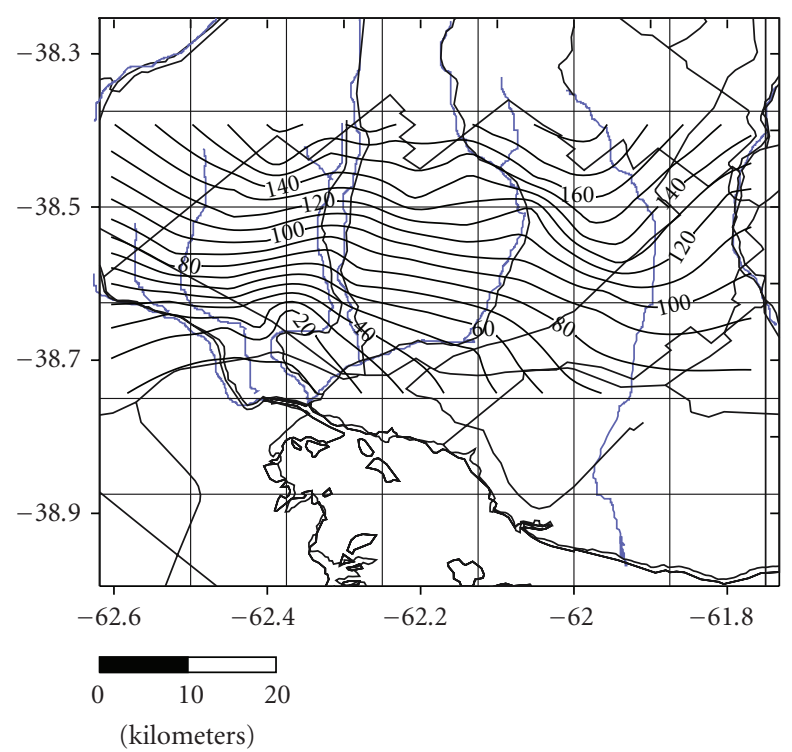

Figure 3: Isohypsic Chart.

between $0.01 \mathrm{mg} / \mathrm{L}$, the overall lowest value found in the study area, and a maximum of $0.13 \mathrm{mg} / \mathrm{L}$ (Figure 6). As in the case of electrical isoconductivity, the highest arsenic concentrations were found in the western sector of the study area.

Groundwater, the main source of supply for the rural population and for some suburban sectors, showed minimum concentrations of $0.01 \mathrm{mg} / \mathrm{L}$ and a maximum of $0.30 \mathrm{mg} / \mathrm{L}$ (Figure 7). The results indicate that concentrations increase towards the southwest, clearly following the direction of the flow towards the ocean. The results obtained for June-July 2007 (Table 2) show an irregular and

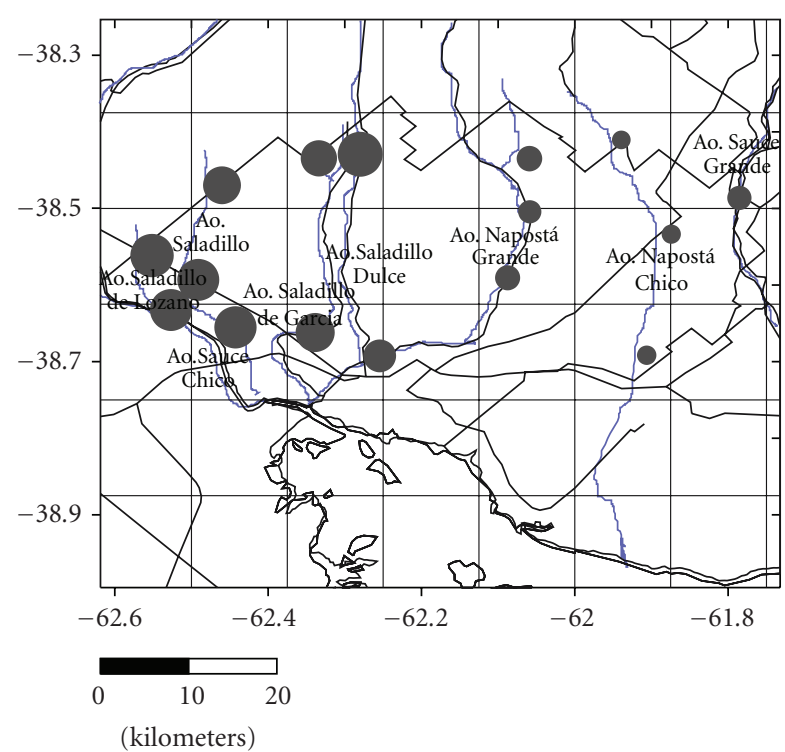

FIgURE 4: Magnitude of electrical conductivity (EC) in surface water

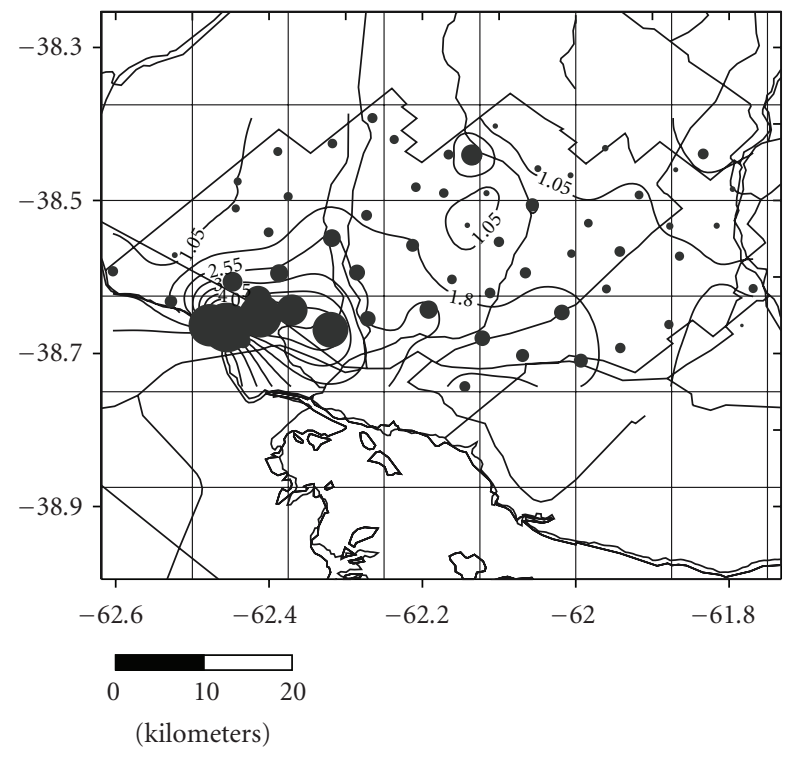

FIgURE 5: Isoconcentrations and magnitude of electrical conductivity (EC) in phreatic groundwater (wells).

asymmetric frequency distribution (Figure 8). The findings show the presence of varying concentrations of arsenic in a complex distribution pattern.

The tolerance level recommended by the WHO [18] for this carcenogenic contaminant in drinking-water is $0.01 \mathrm{mg} / \mathrm{L}$, this same value being cited in the Código Alimentario Argentino [19] and in force since 2007. On the basis of this criterion, only $3.2 \%$ of groundwater and 35\% of surface water sources are within levels recommended for consumption.

The presence of arsenic in the water samples collected from this region of Argentina is due to local geochemical 
TABLE 2: Summary results of arsenic content in phreatic groundwater-Data from samples collected June-July 2007

\begin{tabular}{lcccccc}
\hline No. of samples & $\begin{array}{c}\text { Minimum value } \\
(\mathrm{mg} / \mathrm{L})\end{array}$ & $\begin{array}{c}\text { Maximum value } \\
(\mathrm{mg} / \mathrm{L})\end{array}$ & $\begin{array}{c}\text { Mean } \\
(\mathrm{mg} / \mathrm{L})\end{array}$ & $\begin{array}{c}\text { Standard deviation } \\
(\mathrm{mg} / \mathrm{L})\end{array}$ & $\begin{array}{c}\text { Median } \\
(\mathrm{mg} / \mathrm{L})\end{array}$ & $\begin{array}{c}\text { Range mode } \\
(\% \mathrm{samples})\end{array}$ \\
\hline 63 & 0.007 & 0.302 & 0.081 & 0.060 & 0.070 & $0.07-0.09$ \\
$34.92 \%$
\end{tabular}

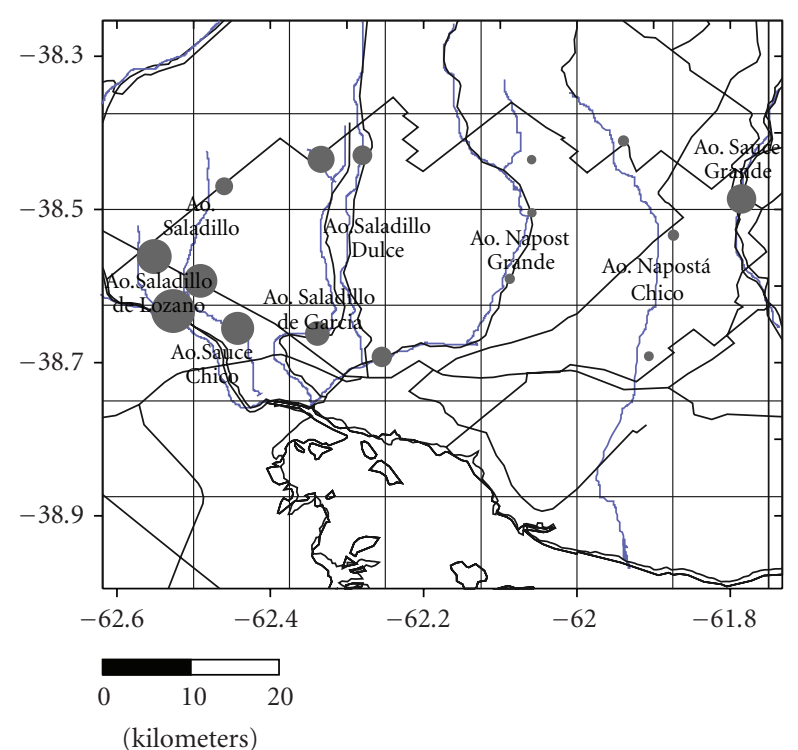

FIGURE 6: Magnitude of arsenic contamination in surface water.

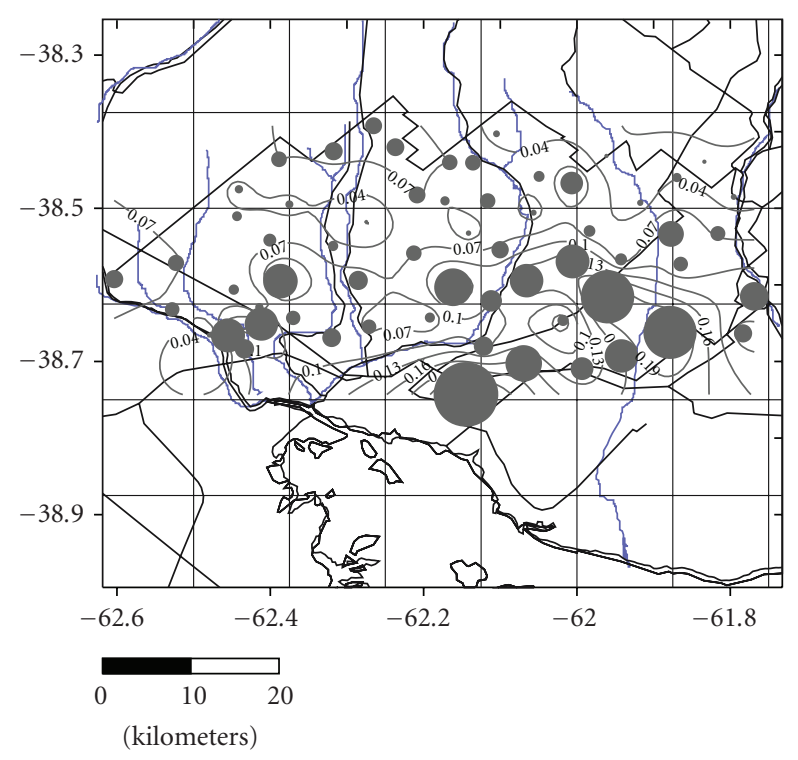

FIGURE 7: Isoconcentrations and magnitude of arsenic contamination in phreatic groundwater (wells).

conditions that facilitate the transfer of naturally occurring arsenic from soils and sediments to the water, favoured by zonal hydrodynamics [15]. No anthropic activities have been observed to contribute to the level of arsenic contamination in the water of the area.

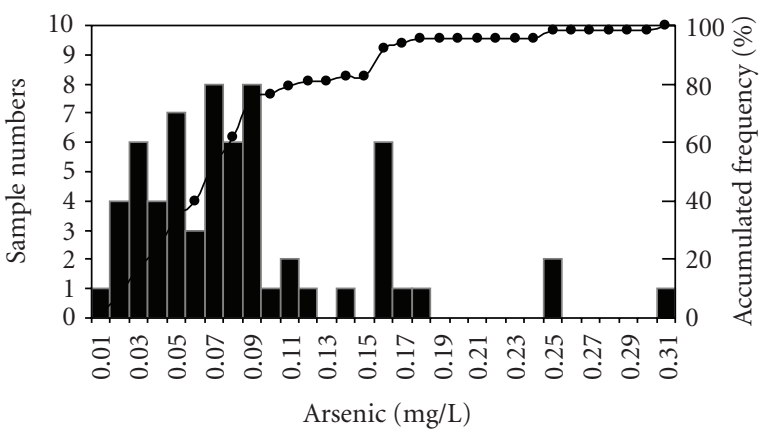

FIGURE 8: Frequency distribution of arsenic concentrations in groundwater. Data from samples collected June-July 2007.

\section{Conclusions}

The results of the current study indicate that approximately $97.0 \%$ of the water samples collected from groundwater wells and surface water sources used for consumption by humans and livestock exceed WHO guideline values for arsenic. These findings show that the population in the area may be exposed to the chronic toxicological effects of hydroarsenicism, placing them at greater risk of contracting a variety of illnesses.

Surface water in the upper reaches of the riverbeds traversing the area is fit for human consumption. However, consumption of water from the riverbeds close to their outlet, where much higher concentrations of the contaminant and of total soluble salts were found, also poses a threat to public health. Since the groundwater studied here constitutes the principal source of drinking water in the zone, it is essential that the findings of this and similar research be made known and applied to practical solutions in preventive medicine, alerting the community to the potential danger associated with this contaminant. Although the government has installed a reverse osmosis plant for As-water treatment in the southwestern sectors of the studied area where in the highest population density is concentrated, the volume of water processed daily does not provide the demand for drinking water for the entire rural community. Nonetheless, this preventative measure sets up a very positive experience to reduce the risks to As-exposure through consumption of contaminated water. These treatment methods could be extended to other affected sectors of the southwestern pampa.

\section{List of abbreviations and definition used}

m: $\quad$ Metre

$\mathrm{mg} / \mathrm{L}$ : Milligrams per litre

dS/m: Decisiemens per metre. 


\section{References}

[1] UNESCO, " 2 ' Informe de las Naciones Unidas sobre el desarrollo de los recursos hídricos en el mundo," 2006, http:// www.unesco.org/water/wwap/wwdr/wwdr2/index_es.shtml.

[2] A. H. Welch and K. G. Stollenwerk, Eds., Arsenic in Ground Water: Geochemistry and Occurrence, Kluwer Academic Publishers, Boston, Mass, USA, 2003.

[3] A. H. Welch, K. G. Stollenwerk, G. N. Breit, et al., "Attenuation of arsenic in Bangladesh sediments-implications for ground-water development," in Managing Arsenic in the Environment-From Soil to Human Health, R. Naidu, E. Smith, G. Owens, P. Bhattacharya, and P. Nadebaum, Eds., pp. 363-377, CSIRO, Collingwood, Australia, 2006.

[4] B. Sahún, S. Niñerola, J. J. Gómez, J. Lillo, P. del Olmo, and A. Hernández, Estudio del contenido de arsénico en la zona central de la Depresión del Duero, Dirección General de Obras Hidráulicas y Calidad de las Aguas, Bibliotecadel Ministerio de Medio Ambiente, 2003.

[5] P. L. Smedley and D. G. Kinniburgh, "A review of the source, behaviour and distribution of arsenic in natural waters," Applied Geochemistry, vol. 17, no. 5, pp. 517-568, 2002.

[6] B. V. Brown, H. M. Valett, and M. E. Schreiber, "Arsenic transport in groundwater, surface water, and the hyporheic zone of a mine-influenced stream-aquifer system," Water Resources Research, vol. 43, p. W11404, 2007.

[7] H. B. Nicolli, A. Tineo, J. Garcia, and C. M. Falcón, "Presencia de arsénico en las aguas subterráneas del sector sur de la Provincia de Tucumán, Argentina. II Taller Arsénico en Aguas," in III Seminario Hispano-Latinoamericano sobre Temas Actuales de Hidrología Subterránea y V Congreso Hidrogeológico Argentino, pp. 107-114, October 2007.

[8] G. Galindo, M. Pachoud, M. A. Herrero, J. L. Fernandez Turiel, and D. Gimeno, "Arsénico y otros elementos traza en agua, en la cuenca del Río Quinto, Villa Mercedes, San Luis. II Taller Arsénico en Aguas," in III Seminario Hispano-Latinoamericano sobre Temas Actuales de Hidrología Subterránea y V Congreso Hidrogeologico Argentino, pp. 99-106, October 2007.

[9] P. Blanes and M. C. Jiménez, "Arsénico y otros oligoelementos asociados en la dorsal agrícola central de la Provincia del Chaco. II Taller Arsénico en Aguas," in III Seminario Hispano-Latinoamericano sobre Temas Actuales de Hidrología Subterránea y V Congreso Hidrogeológico Argentino, pp. 61-68, October 2007.

[10] A. Ayerza, "Arsenicismo regional endémico (keratodermia y melanodermia combinadas)," Boletín de la Academia Nacional de Medicina, vol. 1, pp. 11-24, 1918.

[11] R. Ratnaike, "Arsenic in health and disease," in Managing Arsenic in the Environment: From Soil to Human Health, R. Naidu, G. Owens, P. Bhattacharya, and P. Nadebaum, Eds., pp. 297-309, CSIRO Publishing, Collingwood, Australia, 2006.

[12] C. Hopenhayn, "Arsenic in drinking water: impact on human health," Elements, vol. 2, no. 2, pp. 103-107, 2006.

[13] J. D. Paoloni, C. E. Fiorentino, M. E. Sequeira, and N. Echeverría, "Spatial variability and concentration of arsenic in the groundwater of a region in southwest Buenos Aires Province, Argentina," Journal of Soil and Water Conservation, vol. 55, no. 4, pp. 436-438, 2000.

[14] J. D. Paoloni, M. E. Sequeira, and C. E. Fiorentino, "Mapping of arsenic content and distribution in groundwater in the Southeast Pampa, Argentina," Journal of Environmental Health, vol. 67, no. 8, pp. 50-53, 2005.
[15] M. C. Blanco, C. E. Fiorentino, J. D. Paoloni, M. Sequeira, and M. E. Espósito, "Litologías y calidad de aguas superficiales y subterráneas: Incidencia en el hidroarsenicismo de la región Pampeana Sur. II Taller Arsénico en Aguas," in III Seminario Hispano-Latinoamericano sobre Temas Actuales de Hidrología Subterránea y V Congreso Hidrogeológico Argentino, pp. 93-98, Paraná, Argentina, October 2007.

[16] L. Halicz and G. M. Russel, "Simultaneous determination, by hydride generation and inductively coupled plasma atomic emission spectrometry, of arsenic, antimony, selenium and tellurium in silicate rocks containing the noble metals and in sulphide ores," Analyst, vol. 111, no. 1, pp. 15-18, 1986.

[17] M. Gonzalez Uriarte, "Características geomorfológicas de la porción continental que rodea la Bahía Blanca," in IX Congreso Geológico Argentino, vol. 3, pp. 553-573, Buenos Aires, Argentina, 1984.

[18] WHO (World Health Organization), Guidelines for DrinkingWater Quality. Volume1. Recommendations, WHO, Geneva, Switzerland, 3rd edition, 2004.

[19] "CODIGO ALIMENTARIO PARA USO DEL AGUA POTABLE DE ARGENTINA. Cap. XII," modificatoria del art. 982 (Res. 68/2007 y 196/2007). Buenos Aires, Argentina, 2007. 


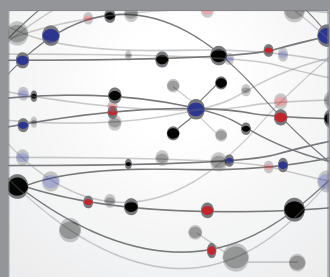

The Scientific World Journal
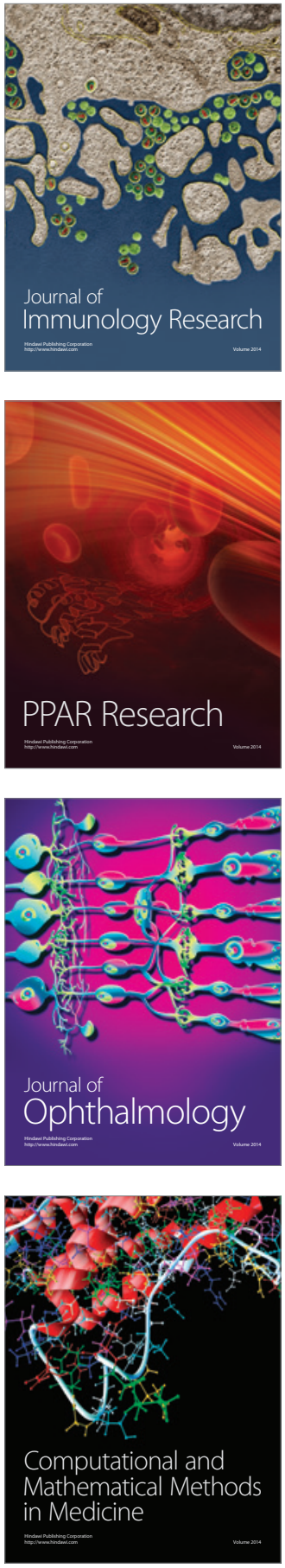

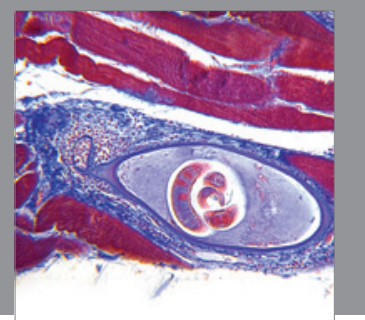

Gastroenterology

Research and Practice
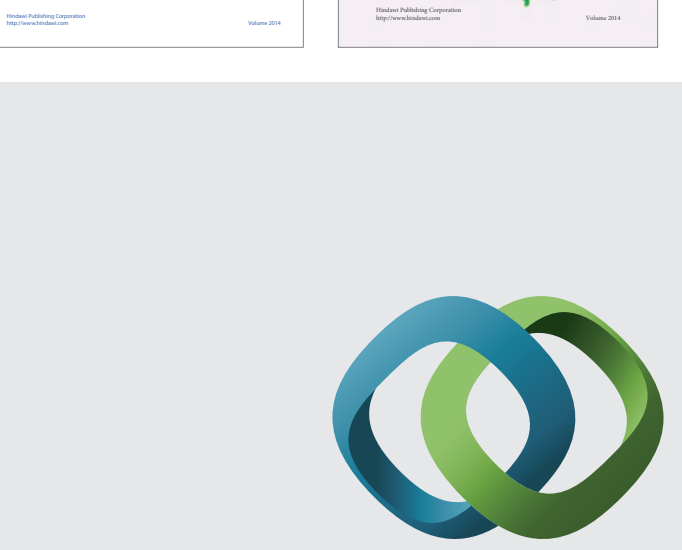

\section{Hindawi}

Submit your manuscripts at

http://www.hindawi.com
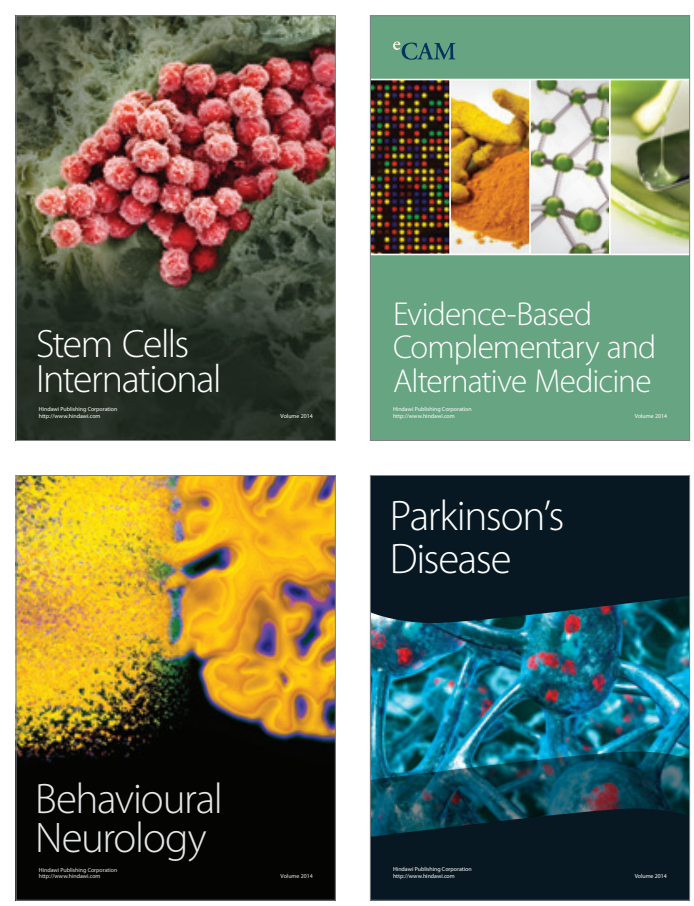

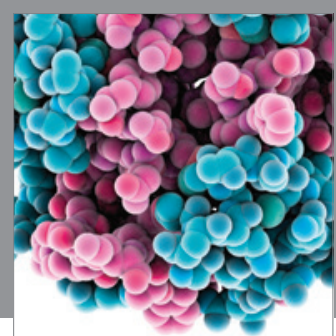

Journal of
Diabetes Research

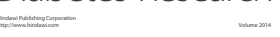

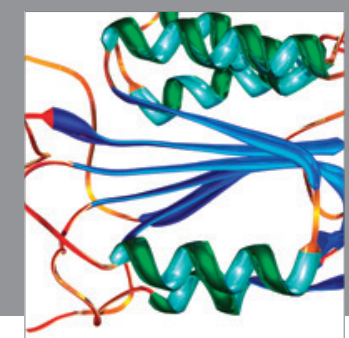

Disease Markers
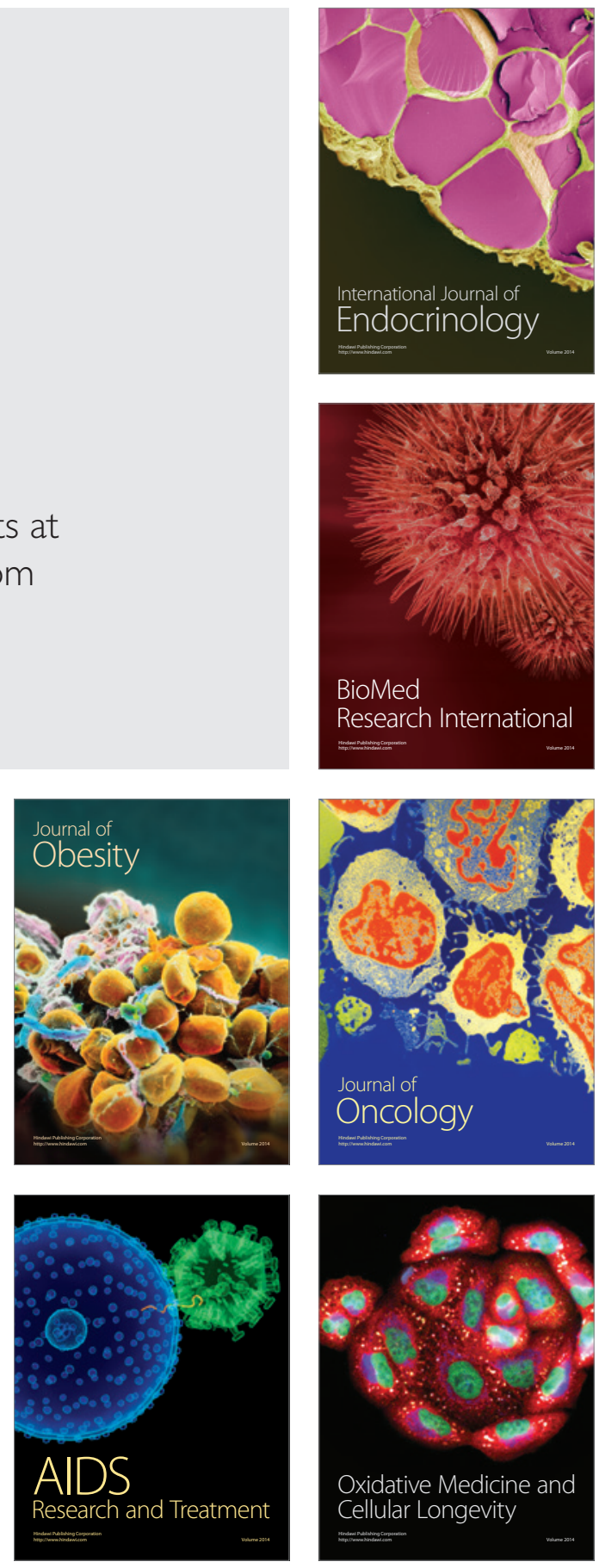